\title{
OS DILEMAS DA FORMAÇÃO DE PROFESSORES DE LÍNGUA INGLESA: AS VOZES DOCENTES
}

\author{
ENGLISH TEACHER'S EDUCATION DILEMMAS: TEACHER'S VOICES
}

DOI: http://dx.doi.org/10.23926/RPD.2526-2149.2019.v4.n1.p166-184.id440

\section{Ana Cláudia Milani Ramos \\ Mestre em Ensino (IFMT) \\ Técnica Administrativa \\ Educacional - TAE (IFMT) \\ ana.ramos@svc.ifmt.edu.br}

\section{Claudia Lucia}

\section{Landgraf Valério}

Doutora em Língua

Portuguesa (PUC-SP)

Professora do Ensino Básico,

Técnico e Tecnológico -

EBTT (IFMT)

Orientadora do Programa de

Pós-graduação Strictu Sensu

em Ensino (IFMT)

claudia.vaelrio@cba.ifmt.ed u.br
Resumo: A escola pública e o ensino de Língua Inglesa têm sido alvo de diversas críticas. Tal julgamento aponta o professor como principal protagonista do fracasso estabelecido no ensino. Todavia, há indícios de que existem outros atores e caminhos a serem seguidos rumo à mudança desse paradigma. Nessa perspectiva, este estudo retrata a investigação realizada, no primeiro semestre de 2018, com duas docentes da rede estadual mato-grossense, cujo objetivo foi trazer suas vozes no que tange à formação inicial e contínua de professores de Língua Inglesa no contexto da escola pública. À luz da pesquisa qualitativa e interpretativa, levantamos os dados por meio de questionários diagnósticos e entrevistas semiestruturadas, os quais foram tratados com base na Análise de Conteúdo, proposta por Bardin (2000). Os resultados sugerem que existem brechas entre as teorias e as práticas pedagógicas e que a falta de formação contínua urge como um fator determinante nos fazeres docentes. Espera-se que este artigo possa contribuir no fomento de reflexões entre professores e cientistas com interesses voltados ao ensino de Língua Inglesa e à formação de professores de escola pública.

Palavras-chave: Formação Inicial, Formação Contínua, Ensino de Língua Inglesa.

\begin{abstract}
Public school and English Language Teaching have been subject of several criticisms. Such judgment points the teacher as the main protagonist of the established failure in teaching. From this perspective, this study depicts the investigation conducted with two teachers from the Mato Grosso state, in the first semester of 2018, whose objective was to bring their voices in relation to the initial and continuing education of English language teachers in the context of the public school. Guided by qualitative and interpretative research, we gathered up data by diagnostic questionnaires and semistructured interviews, which were treated based on Content Analysis, proposed by Bardin (2000). The results suggest that there are gaps between theories and pedagogical practices and the lack of continuing education appears as a determinant factor in teaching practices. It is hoped this article may contribute to the promotion of reflections between teachers and scientists with interests focused on teaching of English language and education of teachers of public schools.
\end{abstract}

Keywords: Initial education; Continuing education; English Language Teaching. 


\section{INTRODUÇÃO}

De forma desvelada, o ensino de Língua Inglesa (LI) das escolas públicas tem sido palco de diversas críticas no que se refere à aprendizagem dos alunos. Tais juízos apontam para uma série de problemas que perpassam a realidade dos professores nas salas de aula, como a falta de infraestrutura nas escolas, crenças e ideologias sobre o fracasso do ensino e, não raro, a falta de formação contínua.

Nesse sentido, a reflexão sobre o fracasso no ensino de línguas traz à tona o ator principal desse contexto: o professor e sua formação. Nesse processo de ensino-aprendizagem de línguas, o docente é apontado como um dos principais motivos de tal fiasco, contudo, existem literaturas que apontam outros atores e caminhos a serem seguidos.

Sob tal visão, inúmeros trabalhos e pesquisas qualitativas buscaram compreender a realidade do ensino de língua inglesa, a formação contínua e estabelecer pontes ou evidenciar brechas entre as teorias de ensino e as práticas pedagógicas. Entre eles, destacamos Celani (2001), Cox e Assis-Peterson (2002, 2008), Barcelos (2007), Leffa (2001), Paiva (2005, 2011), Gimenez $(2005,2009,2011)$, dentre outros.

Dessa maneira, o intuito desse trabalho parte da premissa de que as vozes docentes não podem ser silenciadas, mas sim evidenciadas, assim como suas práticas, suas formações (ou falta delas), para que, dessa forma, passemos a repensar maneiras de ter uma prática pedagógica eficaz e que contribua para um ensino que instigue a criticidade dos aprendizes de línguas, de forma que eles construam e reconstruam os sentidos atribuídos às suas práticas sociais.

Isso posto, nesse artigo apontaremos pertinentes discussões acerca da formação de professores de LI, tanto inicial, como contínua. Para tanto, lançamos a seguinte pergunta de pesquisa: Quais são as percepções que os professores têm sobre suas formações e em que medida a formação contínua interfere nelas?

Os dados foram levantados, no primeiro semestre de 2018, por meio dos instrumentos: questionários diagnósticos, que visaram traçar os perfis das docentes; e entrevistas semiestruturadas, gravadas em áudio. No que tange à análise e à descrição dos dados, utilizamos a técnica proposta por Bardin (2000), a Análise do Conteúdo, esta que utiliza a categorização e subcategorização como forma de selecionar as ideias que se correspondem, as que divergem e as singularidades de cada uma delas.

Como forma de sistematizar este estudo, na primeira parte discorreremos acerca da Formação de Professores de LI, bem como seus dilemas; em sequência apresentaremos os perfis das participantes da pesquisa; para então, evidenciarmos, por meio da Análise de Conteúdo, as 
vozes docentes; e finalmente, tecemos nossas considerações finais acerca da temática supracitada.

\section{REFERENCIAL TEÓRICO}

Nas últimas décadas, há um crescente número de pesquisas em Linguística Aplicada (LA), bem como técnicas, abordagens e práticas de ensino de Língua Inglesa (LI). Apesar do crescimento considerável, as línguas estrangeiras ainda ocupam pouco espaço na educação brasileira devido à sua desvalorização.

Além disso, quando falamos em ensino de línguas em escola pública surgem estereótipos que foram historicamente construídos, descredenciando-a como instituição apta para proporcionar ao aluno ferramentas capazes de colocá-lo em contato com a língua numa perspectiva de uso para que este possa posicionar-se em um mundo de relações sociais, econômicas e políticas globalizadas.

Nesse caminho, Mendes (2006) discorre que a eficácia da prática pedagógica depende diretamente da ampla ação entre alunos e professores, uma vez que o docente tem a privilegiada posição de sugerir, negociar, motivar e orientar as mudanças cabíveis para a fluidez da aprendizagem.

Nesse sentido, Rajagopalan (2009) salienta que o docente deve oportunizar aos seus alunos o contato com diversas variedades de ritmos e sotaques da Língua Inglesa e sugere um pot-pourri de diversas culturas.

Nesse contexto, Magalhães (1997) argumenta que os atores devem estar envolvidos em um constante processo reflexivo de forma que "os sentidos construídos, conteúdos, programas, atividades e materiais didáticos escolhidos, pudessem ser retirados do senso comum dado pelo discurso dominante e questionados" (MAGALHÃES, 1997, p. 172).

Outra discussão que cabe levantar são as crenças que permeiam os espaços escolares de que não se aprende LI em escola pública. Cabe, então, refletirmos: se não é na escola, onde será? Dias e Assis-Peterson (2006) apresentam que professores, alunos, pais e a comunidade escolar de maneira geral não acreditam que os alunos são capazes de aprender. Dias (2006), por meio das entrevistas realizadas em sua pesquisa com membros da comunidade escolar, interna e externa, traz em diversos momentos vozes que corroboram com essa forte crença. Tomamos como exemplo a fala desse pai entrevistado pela autora: "eu acho que é no curso desse negócio... (de inglês), que ele vai aprender mesmo, na escola, não aprende na escola não, na escola é meio assim, pra tapear, pra dizer, né?" (DIAS, 2006, p. 89). 
Como professores de Língua Inglesa, devemos nos envergonhar de tamanho descrédito posto em nosso trabalho. Sabemos do caos instalado no sistema educacional, porém há a necessidade de que tenhamos o empoderamento crítico em nossas aulas e busquemos sempre uma formação crítica para que possamos, assim, restaurar a imagem denegrida do ensino de LI.

Nesse segmento, Paiva (2005) argumenta que se "por um lado, podemos culpar o professor por não dar ao aprendiz um ensino de qualidade, por outro lado, não podemos deixar de ver ambos como vítimas das relações de poder" (PAIVA, 2005, p. 150). Dessa maneira:

o professor mal formado é ele próprio vítima de currículos inadequados, vítima de sua situação econômica, vítima de um contexto desfavorável que não lhe dá acesso a falantes ou a tecnologias que possam compensar essa ausência de contato com uma comunidade de prática em língua estrangeira. Sem o domínio de sua ferramenta básica, fica difícil a qualquer pessoa exercer sua profissão com competência (PAIVA, 2005, p. 150-151).

Nesse segmento, Barcelos (2007) aponta que durante a Licenciatura em Letras o professor em formação precisa adquirir a consciência das responsabilidades da sua futura profissão e das múltiplas e distintas habilidades que envolvem o ensino de línguas. Dessa maneira, o professor deve ser levado a questionar e a refletir acerca de suas capacidades e necessidades de atualizações frente à sala de aula, bem como ter consciência de sua “inconclusão". Somente dessa forma, poderá proporcionar um ensino efetivo no que se refere aos processos de transformação social.

Como forma de fomentar reflexões sobre as práticas pedagógicas, Papa (2008) sugere que sejam criados por professores grupos que promovam ricas discussões sobre os problemas do cotidiano escolar. A autora também argumenta que o desenvolvimento dos professores de línguas estrangeiras deve ser um processo contínuo e inacabado, no qual também cabe refletir sobre as práticas educativas e sociais, tendo em vista que tais ações conduzirão os docentes para mudanças identitárias, bem como de suas crenças.

Nessa perspectiva, Nóvoa (1997) afirma que o docente deve desenvolver o pensamento autônomo de forma que incite a formação crítico-reflexiva e simplifique as dinâmicas da autoformação. $\mathrm{O}$ autor defende que o professor precisa investir em seu desempenho pessoal para ter um trabalho criativo, livre, com projetos, agindo e refletindo sobre suas ações.

Dessa maneira, devemos também olhar o professor sob o prisma pessoal, um ser que possui experiências, emoções, motivações, expectativas e crenças, haja vista que estar em formação requer estar aberto à (re)construção permanente de sua identidade pessoal - que por sua vez, também é a profissional - pois a formação do professor não pode ser desvinculada de 
sua pessoa, uma vez que, conforme a célebre frase de Nias (1991 apud NÓVOA, 2013, p. 15), “o professor é a pessoa; e uma parte importante da pessoa é o professor".

A partir dos autores citados, podemos inferir que a educação é construída por meio do compromisso social, devendo ser baseadas em princípios, inclusão social e valores que promovam a diversidade cultural. Dessa maneira, os professores devem estar aptos para atuarem no cenário contemporâneo, para tanto, o docente precisa conhecer e escolher as metodologias e ferramentas empregadas do ensino de LI.

Nessa direção, Leffa (1988) assevera que no ensino de línguas, a metodologia empregada pode fazer a diferença entre o fracasso e o sucesso da aprendizagem. Todavia, ela não é um fator determinante, uma vez que devem ser levadas em conta inúmeras variáveis que interferem na aprendizagem do aluno.

Em consonância, Moita Lopes (1996) salienta que para evitar que o professor seja um mero executor de métodos alheios, ele necessita de um conhecimento teórico sobre a natureza da linguagem, sabendo mediar a produção de conhecimento sobre os seus usos, além de saber como atuar.

Nesse aspecto, Gimenez (2005) destaca que os docentes de línguas provocam novos direcionamentos quando contestam a concentração da aprendizagem no conteúdo e o abrangem entre a teoria e a prática, e Cox e Assis-Peterson (2002) discorrem a respeito da importância de os professores conhecerem as teorias e abordagens de aprendizagem para fornecer um contexto que engaje efetivamente os alunos.

Nesse viés, os estudos voltados para a área de formação de professores e ensino língua inglesa têm sido primordiais para despertarem a consciência dos professores como agentes críticos em sala de aula e por meio do ensino, eficiente, mudar as práticas e ações didáticopedagógicas, haja vista que, se nada fizermos, o ensino de línguas não mudará para uma realidade melhor.

Após tais considerações, seguimos para a apresentação das participantes da pesquisa, tendo como base o questionário diagnóstico respondido por elas.

\section{OS DILEMAS DA DOCÊNCIA}

Despertar a criticidade, o conhecimento e contribuir para o deslocamento do local social que o ser ocupa é uma tarefa estimável que demanda entrega pessoal e dedicação daqueles que o fazem. Nesse sentido, apresentamos os perfis das professoras participantes desta investigação. Entretanto, segundo Bogdan e Biklen (1994), as identidades dos sujeitos participantes da 
pesquisa devem ser protegidas para que a informação que o investigador recolhe não possa lhes causar qualquer tipo de transtorno ou prejuízo, sendo assim, as participantes serão identificadas como "Professora Amanda" e "Professora Bianca".

Destacamos, todavia, que ambas são professoras de Língua Inglesa e exercem suas atividades profissionais em uma escola pública estadual, localizada na região central da capital mato-grossense.

Em atenção à ética na pesquisa qualitativa, salientamos que as professoras aceitaram participar voluntariamente desta investigação - sem quaisquer privilégios, sejam eles de caráter financeiro ou de outra natureza - e que assinaram o Termo de Consentimento Livre e Esclarecido (TCLE), este que lhes garantiu todos os cuidados necessários e o respeito aos seus direitos individuais.

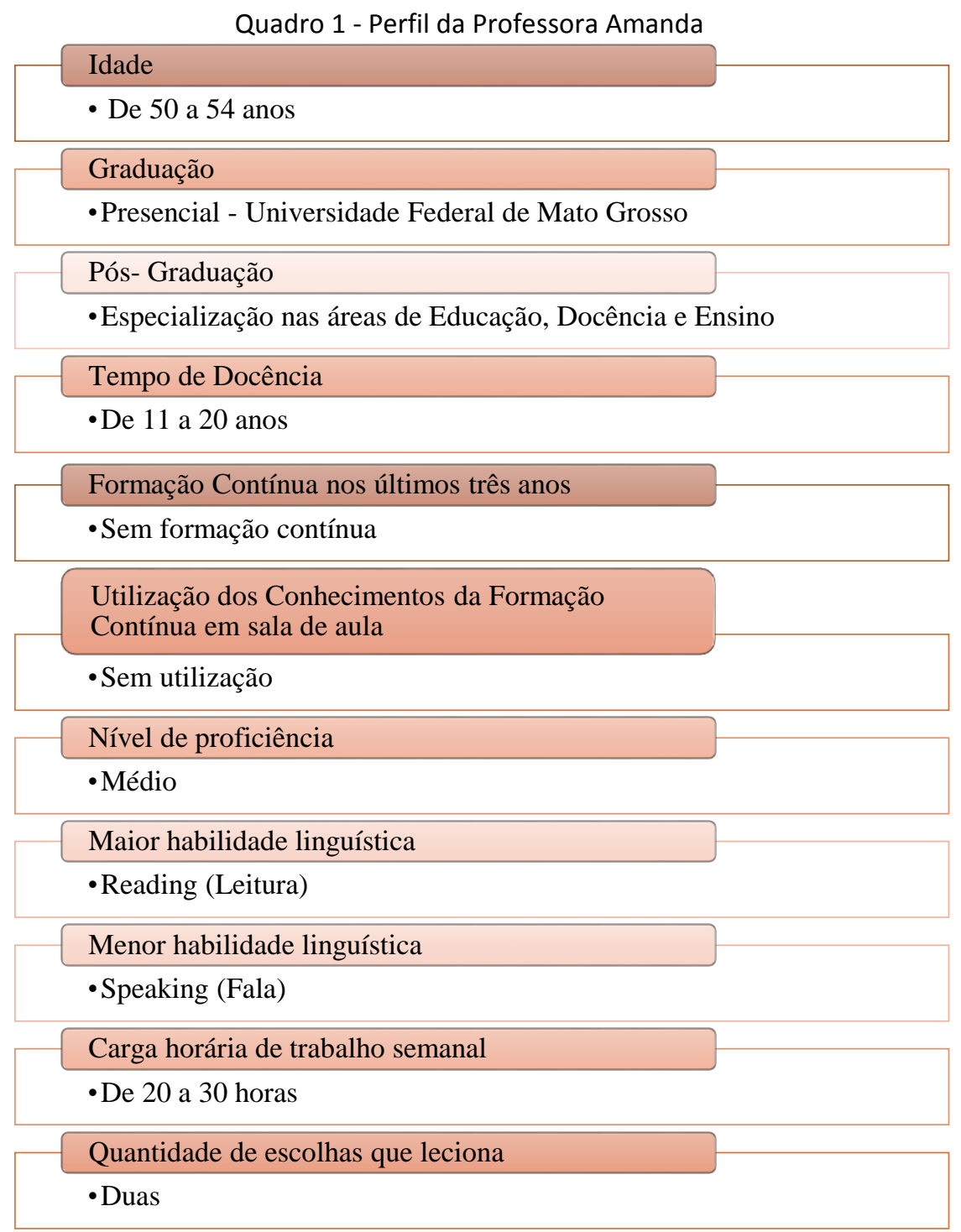

Fonte: Elaborado pela pesquisadora, 2018. 
Conforme disposto no "Quadro 1", a Professora Amanda tem de 50 a 54 anos, graduouse em Letras-Português/Inglês, na modalidade de curso presencial, pela Universidade Federal de Mato Grosso. Possui pós-graduação nas áreas de educação, docência e ensino, todavia, não faz, efetivamente, um curso de formação contínua há pelo menos três anos.

Quanto ao magistério, a docente apontou ter de 11 a 20 anos de experiência em sala de aula, mas que, devido à falta de cursos de formação, não tem utilizado os conhecimentos oriundos deles em suas práticas em sala de aula.

Quadro 2 - Perfil da Professora Bianca

\begin{tabular}{|l|}
\hline Idade \\
\hline De 40 a 49 anos \\
\hline Graduação \\
\hline Presencial - Universidade Federal de Mato Grosso \\
\hline Pós- Graduação \\
\hline Tempo de Docência \\
\hline Pe 21 a 25 anos \\
\hline Formação Contínua nos últimos três anos \\
\hline Sem formação contínua Área de Linguagens \\
\hline Utilização dos Conhecimentos da Formação \\
\hline Contínua em sala de aula \\
\hline Sem utililação \\
\hline Pível de proficiência \\
\hline • Médio \\
\hline Menoro 20 a 30 horas habing (Fala) \\
\hline Meading (Leitura) \\
\hline Meridade de escolhas que leciona \\
\hline
\end{tabular}

Fonte: Elaborado pela pesquisadora, 2018.

De acordo com o "Quadro 2", a Professora Bianca tem de 40 a 49 anos, possui de 21 a 25 anos de docência, é formada em Letras-Português/Inglês, na modalidade de curso presencial, pela Universidade Federal de Mato Grosso. Tem pós-graduação na área de linguagens, mas assim como Amanda, também não participou de cursos voltados à formação contínua nos 
últimos três anos, dessa maneira, não aplicou os conhecimentos advindos deles em suas práticas docente.

Ambas as docentes declararam ter nível intermediário em se tratando de fluência em Língua Inglesa, e possuem maiores habilidades linguísticas na leitura, assim como as maiores dificuldades são referentes ao desempenho da fala. Há coincidência também no fato de ambas trabalharem em duas escolas e possuírem em cada uma delas uma carga-horária dentre 20 a 30 horas semanais, considerando a hora-atividade. Sendo assim, suas atividades docentes compreendem dentre 40 a 60 horas semanais. Dessa carga-horária, 30 horas semanais correspondem ao trabalho que realizam na escola estadual, lócus da presente investigação, sendo 20 delas em sala de aula e 10 horas como hora-atividade, as quais são cumpridas no ambiente de trabalho. Dessas 10 horas destinadas às atividades relativas à profissão docente, 04 horas são destinadas à participação da Sala do Educador, conforme previsto na Lei Complementar $\mathrm{n}^{\circ} .50$, de 01 outubro de 1998 (MATO GROSSO, 1998).

Durante as entrevistas, quando questionadas acerca das respostas lançadas no questionário, as docentes destacaram a falta de tempo como um fator determinante no que tange ao desempenho linguístico. Sob esse prisma, evidenciamos as palavras das professoras nos excertos seguintes.

Excerto 1:

[...] gostaria de ter mais tempo pra fazer conversação, porque realmente nessa parte ainda sou meio travada [...]. Devido a minha carga horária eu não tenho mais tempo pra tá conversando, praticando a oralidade (Professora Bianca).

Tais afirmações são bem mais comuns do que gostaríamos, uma vez que são inúmeras as vozes que trazem a insegurança na função comunicativa, alegando excessivas cargas-horárias de trabalho a ponto de não conseguirem sequer fazer cursos de formação para aperfeiçoamento das suas práticas pedagógicas.

\section{Excerto 2:}

Eu não tenho tempo para fazer cursos, é ... pelo... por eu trabalhar nos três períodos eu não tenho condições, né? (Professora Amanda).

Nesse sentido, Cox e Assis-Peterson (2002) ao distinguirem o "ser" do "estar" professor de Inglês, aludem à luta que aqueles que "são" professores de LI travam para que possam, de fato, contribuir para com a aprendizagem de inglês dos estudantes de escola pública. As autoras enumeram, dentre outros obstáculos: número de aulas insuficientes, salas numerosas, salário baixo, bem como a jornada excessiva de trabalho, que é relatada pelas professoras Amanda e Bianca, como empecilho para a busca de melhorar sua competência linguística. Fazendo um 
contraponto entre a fala das participantes da pesquisa com o estudo realizado pelas autoras supracitadas, pode-se inferir que a jornada de trabalho excessiva se constitui como uma barreira à qualificação profissional não apenas para Amanda e Bianca, mas está no cerne da questão da qualidade do ensino-aprendizagem de LI, tendo em vista sua constante na vida dos profissionais da área.

Uma política que não privilegie uma formação contínua de qualidade põe em xeque inúmeras problemáticas e expõe o professor como matéria-prima barata das escolas. Vale salientar que o intuito não é de julgar as participantes da pesquisa, mas de retratar os acontecimentos e olhar de maneira mais altruísta para com a profissão que gera o desenvolvimento da nação e, com isso, muda vidas.

Nessa lógica, quando algum docente de LI aponta que sua maior dificuldade é em falar a língua a qual ensina, traz à tona uma falha naquilo que o singulariza das outras ciências que é o fato dele ser bilíngue. $\mathrm{O}$ domínio da língua estrangeira deveria ser uma característica inerente àqueles que a ensinam, pois um professor não poderá ajudar seus alunos a desenvolverem toda a complexidade da função comunicativa se isso lhes forem negligenciados em sala de aula. Da mesma forma, os docentes não poderão suprir tais necessidades sem que as políticas públicas fomentem a melhoria da formação inicial e a promoção da formação contínua.

Excerto 3:

Na parte da gramática é mais fácil, né?! Agora, a parte da oralidade, a parte do falar em inglês é mais difícil (Professora Amanda).

Nessa perspectiva, Gimenez (2009) aponta que os professores estão demostrando níveis insatisfatórios de proficiência linguística e despreparo nas adversidades das salas de aulas. Tais situações seriam fruto de políticas educacionais que não incentivam o aprendizado de línguas estrangeiras, essas que não conseguiram atingir as camadas mais pobres da população, e devido à desvalorização da profissão docente. Sob tal aspecto, Cox e Assis-Peterson (2008) argumentam que a visão desprestigiada do professor de línguas faz-se presente, inclusive, nas mídias e repercutem nas crenças populares.

Para Nóvoa (2011), as práticas docentes são alimentadas da ideia pública de que ensinar é simples, fato que contribui para o desprestígio da profissão.

À vista disso, de um lado, Oliveira (2009) faz uma severa crítica às Instituições de Ensino Superior (IES), que têm sido cúmplices no insucesso do ensino, e defende que "os cursos superiores responsáveis pela formação de professores de línguas estrangeiras não estão cumprindo seu papel satisfatoriamente" (OLIVEIRA, 2009, p. 29). A autora ainda frisa que "na 
medida em que uma universidade confere o diploma de licenciatura em determinada língua estrangeira a uma pessoa que não domina essa língua, ela contribui decisivamente para que o ensino de línguas nas escolas públicas não tenha uma perspectiva futura positiva" (Idem). Por outro lado, devemos nos atentar que o processo de formação é gradual, contínuo e inacabado, sendo assim, são necessárias a manutenção e a incorporação de novos conhecimentos. Então, não conferir o diploma àqueles que cumpriram o currículo universitário por não terem alcançado a proficiência é, sem dúvidas, uma exclusão social, posto que muitos adentram a licenciatura em Letras sem o conhecimento básico da língua estrangeira e nem todos tiveram a oportunidade - financeira, motivacional ou temporal - de fazer cursos paralelos ou antecedentes à graduação.

Nesse segmento, Gimenez (2011, p. 53) discorre que "é necessário considerar os fatores que historicamente constituem os indivíduos e os sentidos que os movem, assim como as condições materiais e o desenvolvimento que potencialmente podem produzir", ou seja, um profissional em formação não pode ser suprimido pelo sistema educacional, mas sim estimulado e incitado a dar o seu melhor. Todavia, é preciso o amparo da formação contínua e das políticas públicas favoráveis para que ele consiga colocar em prática toda sua capacidade, técnica, eficiência e competência em sala de aula.

Isso posto, discorremos no tópico seguinte acerca da importância da formação inicial e contínua, para tanto, evidenciaremos as vozes de Amanda e Bianca por meio da Análise de Conteúdo das entrevistas.

\subsection{FORMAÇão INICIAL}

Um bom exemplo é primordial em nossa educação, uma vez que como indivíduos tendemos a efetivar atitudes e posicionamentos análagos àqueles que nos cercam. Nessa perspectiva, ao se falar em formação inicial, devemos nos atentar aos nossos mestres da academia, haja vista que carregamos muito deles dentro de nós, sejam pelas contribuições, sejam pelas frustrações. Assim sendo, no "Quadro 3" apresentamos as subcategorias com as manifestações das professoras Amanda e Bianca, no que tange à formação inicial.

Quadro 3 - Formação Inicial

Admiração como fator $\quad$ Na trajetória que eu tive é... principalmente na área de Língua Inglesa foram de aprendizagem excelentes professores e professoras, é... inclusive a professora Rosa [...] me motivaram muito e me fizeram tomar gosto pela Lingua Inglesa cada vez mais [...] foram é ...incentivadoras nas minhas práticas de sala de aula (Professora Amanda). 


\begin{tabular}{|c|c|}
\hline & $\begin{array}{l}\text { [...] a aí eu passei pelas mãos da professora Rosa...que, assim, eu considero top, } \\
\text { pra mim é um modelo de professora [...] comprometimento de professora, acho } \\
\text { que não chego aos pés dela não, não chego mesmo (Professora Bianca). }\end{array}$ \\
\hline & $\begin{array}{l}\text { [...] é... eu creio que...pra qualquer tipo de aprendizagem seja muito importante } \\
\text { afetividade nessa aprendizagem, porque quando o aluno não gosta de determinado } \\
\text { professor, ou não gosta de determinada disciplina, às vezes, ele não vai bem, } \\
\text { então, eu creio que essa... isso daí, foi uma coisa que me norteou na...nas minhas } \\
\text { práticas em sala de aula (Professora Amanda) }\end{array}$ \\
\hline & $\begin{array}{l}\text { [...] no incentivo mesmo para que nós não desistíssemos, porque ... muitas vezes } \\
\text { é... estávamos sobrecarregadas, é sobrecarregada na faculdade todo mundo } \\
\text { trabalha né, e depois vai estudar a noite, é muitas atividades pra fazer e o curso } \\
\text { de letras demanda muita leitura. Mas... a maneira com que elas conduziam as } \\
\text { aulas tornavam-se, assim, mais... mais fáceis, mais, assim... é mais motivadoras } \\
\text { (Professora Bianca). }\end{array}$ \\
\hline $\begin{array}{c}\text { Alerta na Formação } \\
\text { Inicial }\end{array}$ & $\begin{array}{l}\text { Infelizmente nós estamos com alguns profissionais que estão começando a } \\
\text { carreira que digo que vai ser difícil, muito difícil [...] esse ano me apareceu uma } \\
\text { pra fazer regência. Ela queria que eu assinasse a regência [...] eu tive que } \\
\text { conversar com o coordenador e pedisse que explicasse pra ela que eu não ia } \\
\text { assinar a regência pra uma pessoa que não fez a regência [...] infelizmente nós } \\
\text { temos profissionais que estão sendo formados, assim [...] você olha e fala: senhor } \\
\text { é possível? (Professora Bianca). }\end{array}$ \\
\hline
\end{tabular}

Fonte: Elaborado pela pesquisadora, 2018.

Ao indagarmos às participantes da pesquisa quanto às suas experiências na graduação, deparamo-nos com um fator de suma importância em suas formações acadêmicas: a admiração como fator de aprendizagem, que aparece como suporte e motivação para as práticas pedagógicas.

Sob tal visão, Paiva (2011, p. 44) salienta que "quando os aprendizes gostam de seus professores e os admiram, isso contribui para que eles imaginem as comunidades de falantes de inglês e aceitem os desafios da aprendizagem". E ainda nos alerta que "é provavel que muitos professores não tenham ideia de seu poder enquanto modelos de membros dessas comunidades ou, ainda, como podem desestimular seus aprendizes com sua inércia” (Idem).

Nessa perspectiva, Gimenez (2011, p. 52) detectou, em seus estudos sobre a relação entre crenças, biografias e identidades, uma enorme identificação dos docentes com seus antigos mestres, no entanto, "dos que causaram fracasso, o distanciamento, dos que foram considerados responsáveis pelos sucessos, o desejo de fazer igual”.

Assim sendo, vale lembrar que Rajagopalan (2003) nos alerta de que não podemos jamais esquecer que estamos envolvidos em uma tarefa eminentemente política, não neutra e ideologicamente orientada.

Diante de tal lógica, fica exposto que não existe prática pedagógica isenta de ideologias, fazendo com que na bagagem de experiências do professor em formação sejam encontradas vestígios de circunstâncias políticas e sociais, por conveniências pessoais, por métodos 
didáticos oriundos da academia e por um acervo de ações e atitudes que acabam delineando a sua identidade docente.

Nessa acepção, os docentes que passam pela nossa vida acadêmica sempre deixam um pouco de si, seja pelo bem que é um modelo norteador das práticas pegadógicas, de como ser e como fazer; seja pelo mal, uma via pela qual não queremos seguir.

Quanto à segunda subcategoria, a Professora Bianca revelou sua preocupação quanto aos futuros docentes que estão saindo da graduação, pois estão apresentando níveis alarmantes nas regências e até mesmo tentativas de fraudes.

Nesse viés, Nóvoa (2001, n.p) ressalta que o aprender contínuo é essencial na profissão docente e deve concentrar-se em dois pilares: "a própria pessoa do professor, como agente, e a escola, como lugar de crescimento profissional permanente".

Diante do exposto, entendemos que a formação inicial tem enorme peso no desenvolvimento profissional dos discentes das universidades. Entretanto, para isso é necessário maior fomento por parte do Governo Federal. Nesse âmbito, tomamos como exemplo positivo o Programa Institucional de Bolsa de Iniciação à Docência (PIBID) que está em vigor há alguns anos. Tal programa, conforme o Ministério da Educação (MEC), tem por objetivo a elevação das “ações acadêmicas voltadas à formação inicial de professores nos cursos de licenciatura das instituições de educação superior, assim como inserir os licenciandos no cotidiano de escolas da rede pública de educação, promovendo a integração entre educação superior e educação básica" (BRASIL, 2007, n.p.).

Nesse sentido, Celani destaca que "na Universidade os saberes disciplinares superam o desenvolvimento de competências, e o grande problema é a brecha entre o discurso da universidade e o cotidiano, principalmente o cotidiano que o professor recém-formado vai encontrar na escola" (CELANI, 2001, p. 36). Para a autora, significa que o professor deve ter a atitude reflexiva inserida em sua identidade profissional. A autora também destaca "o senso de responsabilidade com a cidadania como mola propulsora para uma atuação em rede, na escola e na comunidade educacional. Isso fará com que se sinta membro de uma profissão e responsável por ela" (Idem).

De acordo com o Parecer CNP/CP 9/2001, que dispõe sobre as diretrizes curriculares nacionais para a formação de professores da educação básica, em nível superior, curso de licenciatura, de graduação plena, para que melhoremos a formação docente é necessário buscar mudanças efetivas nos processos e nos currículos. Nesse sentido, o documento salienta que: 
faz-se necessária uma revisão profunda dos diferentes aspectos que interferem na formação inicial de professores, tais como: a organização institucional, a definição e estruturação dos conteúdos para que respondam às necessidades da atuação do professor, os processos formativos que envolvem aprendizagem e desenvolvimento das competências do professor, a vinculação entre as escolas de formação inicial e os sistemas de ensino de modo a assegurar-lhes a indispensável preparação profissional (BRASIL, 2001, p. 11).

Ademais, apreendemos que o ambiente escolar está carregado de significados em plena, abundante e constante transformação. A escola pública permanece sendo a instituição mais complexa de todos os serviços oferecidos pelo Estado, considerando que o planejamento dos serviços que presta à sociedade deve ser discutido e programado, conforme a realidade na qual está inserida e com a participação de toda a comunidade escolar.

Sob nossa ótica, para o acadêmico, o momento de imersão no universo múltiplo é uma oportunidade única de explorar as várias nuances que compõem o cenário escolar, suas generalidades, suas especificidades e suas perspectivas.

A união entre teoria e prática desses programas transforma a academia em uma verdadeira pesquisa-ação e gera um retorno ímpar à sociedade. Como num efeito dominó, tende a disseminar conhecimento e capacitação para o magistério. Caso contrário, ainda vamos nos deparar com esses discursos de "medo da sala de aula" e "medo da escola pública" nos cursos de graduação, bem como de falhas nos estágios supervisionados.

Nesse contexto, compreendemos que é vital que os professores recebam boa formação inicial e alcancem autonomia em sua formação contínua, firmando-se como profissionais respeitados, valorizados e alcançando a visibilidade social que merecem, conforme discorreremos no tópico seguinte.

Formação Contínua

Para Leffa (2001), o professor de Língua Estrangeira (LE), ao ensinar, toca o ser humano em sua essência, tanto pela ação que oportuniza a mudança e a capacidade de evolução, quanto pelo objetivo do verbo em si, que é a língua. Todavia, tal prerrogativa implica em longo e pesado investimento na formação dos professores de línguas estrangeiras. Nesse sentido, ele aponta a diferença entre treinar e formar professores.

De acordo com o autor, ao treinar o docente, estamos apenas capacitando-o para efetuar determinada tarefa, no entanto, a formação lança o olhar para além do aqui e agora, uma vez que é um ciclo contínuo que envolve teoria, prática e reflexão. Leffa (2001) ainda sugere que o que se pode fazer "é alertar o futuro professor que o conteúdo que ele está recebendo agora através dos livros é um conteúdo de valor temporário, e que muito brevemente, como muitos outros produtos fabricados pelo homem, terá sua validade vencida" (LEFFA, 2001, p. 336). 
Isso posto, evidenciamos no "Quadro 4" as vozes das docentes sobre a atribuição de importância à formação contínua e o papel das políticas públicas.

Quadro 4 - Formação Contínua

\begin{tabular}{|c|c|}
\hline \multirow[t]{2}{*}{ As políticas públicas } & $\begin{array}{l}\text { A gente faz a crítica, mas com o tempo a gente fica desanimado de falar } \\
\text { sobre isso. Quando eles falam em formação de professores, é... eu acho que } \\
\text { a formação de professor só vale a pena quando o professor busca a } \\
\text { formação, ele sabe onde está deficiente, ele sabe o que procurar [...] a } \\
\text { formação do professor quando ele vai atrás e não é imposto pra ele, mas ele } \\
\text { vê uma deficiência dele e ele corre atrás, essa formação tem retorno. Agora, } \\
\text { quando nos obrigam a ficar numa sala de quatro paredes, estudando alguma } \\
\text { coisa que a gente já sabe, que a gente já ouviu falar e vem uma pessoa e fala } \\
\text { que a gente nunca leu aquilo, porque o que acontece é isso (Professora } \\
\text { Bianca). }\end{array}$ \\
\hline & $\begin{array}{l}\text { [...] Infelizmente, professores da rede estadual não têm a oportunidade de } \\
\text { fazer, a não ser que ele faça num horário fora da sua sala de aula ou nos } \\
\text { finais de semana, mas tem que ser todos aqui em Cuiabá, porque não tem } \\
\text { como viajar [...] inclusive, me parece que o Governo do Estado não está } \\
\text { aceitando que ninguém faça é... pegue afastamento pra fazer mestrado } \\
\text { (Professora Amanda). }\end{array}$ \\
\hline \multirow[t]{2}{*}{$\begin{array}{l}\text { A importância atribuída a } \\
\text { Formação Contínua }\end{array}$} & $\begin{array}{l}\text { [...] qualquer disciplina. É necessária a formação [..] Ah... ela influencia } \\
\text { diretamente[...] a busca pela formação é necessária, mas ainda há um } \\
\text { buraco entre o lado de lá e o lado de cá, que é quem está na linha de fogo } \\
\text { (Professora Bianca). }\end{array}$ \\
\hline & $\begin{array}{l}\text { Eu creio que sim, muito importante! Ah! Justamente pra nós estarmos nos } \\
\text { atualizando dentro de sala de aula, porque os alunos são muito dinâmicos, } \\
\text { né? E... se você não estiver acompanhando o que está acontecendo no } \\
\text { momento, é... você fica defasado, você fica pra trás. Quando você faz } \\
\text { reciclagem você vê... é... nas oficinas, por exemplo, você vê atividades } \\
\text { diferenciadas que você pode trabalhar com seus alunos pra poder incentiva- } \\
\text { los também a gostar da língua inglesa (Professora Amanda). }\end{array}$ \\
\hline
\end{tabular}

Fonte: Elaborado pela pesquisadora, 2018.

As docentes apontam o que muitos professores no Estado de Mato Grosso e no Brasil passam: a falta de incentivo por parte das políticas para sua formação contínua. Amanda destaca que não recebe estímulos para participação em cursos, seminários e nem desenvolver atividades voltadas à pesquisa diante do cenário político em que se encontra o Estado de Mato Grosso. Sem saber, então, como contornar as adversidades impostas, acaba cedendo ao desânimo e abrindo mão da formação contínua.

Bianca também salienta que os cursos ofertados pelo Estado são voltados para áreas diversas, sem enfoque na língua a qual leciona. E ainda defende que o profissional deve procurar esteio naquilo que sente necessidade como professor, nos aspectos e particularidades que cada um sabe que precisa melhorar e desenvolver, ou seja, naquilo e na medida em que percebe sua dificuldade. Entretando, têm sido ofertados cursos descontextualizados da realidade e dos anseios educacionais dessa profissional.

Diante disso, a professora traça uma diferença entre a escola particular, na qual trabalhou por alguns anos, com sua realidade de escola pública, conforme o excerto 4. 
Excerto 4:

[...] é uma escola que sempre deu vários cursos pra gente, cursos realmente interessantes, palestras com pessoas de fora [...] nós tínhamos cursos voltados para nossa área de língua inglesa, então, nós tínhamos um acompanhamento com a área de língua inglesa (Professora Bianca).

Tal discurso faz 'desabar o teto do Estado', que mostra não reconhecer os profissionais da educação como agentes de diferentes ciências e precisam de formação específica em sua área de atuação, o que causa desalento ao professorado.

Esteves (1999, p. 97) afirma que "os professores enfretam circunstâncias de mudança que os obrigam a fazer mal o seu trabalho, tendo que suportar críticas generalizadas que, sem analisar essas circunstâncias, os considera como responsáveis imediatos pelas falhas do sistema de ensino". O autor utiliza o termo "mal-estar docente" para caracterizar os efeitos negativos das circunstâncias pedagógicas, psicológicas e sociais que podem abalar o professor e comprometer o exercício da sua função, tal como o desencanto e a insegurança.

Nesse sentido, Papa (2008) argumenta sobre a importância de se entender que o desenvolvimento dos professores de línguas estrangeiras é um processo contínuo e inacabado, em que também cabe refletir sobre as práticas educativas e sociais, tendo em vista que tais ações conduzirão os docentes para mudanças identitárias, bem como possibilitarão a reformulação de suas crenças.

Bianca argumenta que "professor sabe onde está deficiente" e precisa de suporte para ter maior eficácia em seu ensino. Nessa direção, Almeida Filho (2005, p. 20) argumenta que "a consciência do que somos (que abordagem temos) e do que fazemos (que competências revelamos em configurações específicas) é um grande e necessário passo no processo de desenvolvimento e mudança".

Dias e Assis-Peterson (2006) discorrem que "se quisermos colaborar no processo de uma educação libertadora e emancipatória, almejando uma sociedade economicamente viável e democraticamente contextualizada, precisamos viabilizar uma escola que acolha a participação ativa de seus membros e aceite habilidades de pensamento crítico que vão além do que a escola tem oferecido até agora" (DIAS; ASSIS-PETERSON, 2006, p. 107).

A consciência da importância da formação contínua está presente nos discursos das professoras, o que nos parece ser uma semente a ser cultivada, pois é o princípio de uma reflexão que deve estender-se nas práticas diárias das docentes. Nessa perspectiva, apesar da falta de tempo, Amanda e Bianca declararam que fazem cursos online para não ficarem totalmente desatualizadas. 
Excerto 5:

[...] ]hoje eu não faço porque eu não tenho tempo, quer dizer, faço esse online, graças a Deus, né?! (Professora Bianca).

Posto isso, entendemos como relevante o papel da Educação à Distância (EaD), nesse quesito. Entretanto, mesmo colaborando, os cursos ainda são, por vezes, ineficazes, pois serviram apenas como estepe na formação e não conseguiram despertar nessas docentes o real interesse e envolvimento que demanda a formação contínua.

Sob tal prisma, Freire (2005) argumenta que "na formação permanente dos professores, o momento fundamental é o da reflexão crítica sobre a prática. É pensando criticamente a prática de hoje ou de ontem que se pode melhorar a próxima prática" (FREIRE, 2005, p. 165).

\section{CONSIDERAÇÕES FINAIS}

Nosso estudo verificou que, de maneira geral, ainda há uma grande desvalorização do ensino de LI e, portanto, é preciso mudar os contextos e não apenas os professores e sua formação. Para isso, são necessárias políticas educacionais que visem ao investimento tanto na formação inicial como na contínua, de forma que sejam aproximados os conhecimentos práticos dos acadêmicos, bem como a articulação entre ensino e pesquisa. Políticas que sejam pontes sobre as lacunas que separam os que pensam a educação e os que nela agem, ou, nas palavras da Professora Bianca: os que estão na "linha de fogo".

Entendemos o ensino como um compromisso social que é construído por meio de relações estáveis, inclusão social, promoção da diversidade cultural, valores e desenvolvimento do pensamento crítico. Afinal, o professor da contemporaneidade precisa ter o perfil capaz de agir sobre as urgências do dia a dia, ser mediador do conhecimento e conseguir transformar o saber em saber-fazer.

Ademais, os professores precisam colocar em uso seus conhecimentos e ainda necessitam mobilizar a comunidade escolar, familiares e sociedade como um todo para a emancipação humana, trabalhar no intuito de desenvolver no discente a criticidade, assim como quebrar os paradigmas de que escola pública não é lugar de aprender língua inglesa.

Salientamos, portanto, que, assim como a formação inicial, a formação contínua mostrase mais que necessária em um processo inacabado, em que os professores devem buscar, cada vez mais, melhorias em suas práticas, refletir sobre elas, para que, assim, possam promover um ensino contextualizado, crítico e de qualidade. 
Nesse prisma, cada um em sua esfera precisa assumir suas responsabilidades. Amanda e Bianca encarregam-se das suas. Então, é urgente, e até tardia, a necessidade de o poder público abraçar as que lhe cabem e parar de negligenciar a educação.

Nossas percepções são que as professoras precisam de formação contínua voltada para o ensino da Língua Inglesa para que, assim, possam ressignificar suas ideologias e práticas. Nesse viés, entendemos que ser professor é tecer um caminho que norteie seus alunos; é arriscar; é desdobrar-se por crianças e adolescentes de pais que, muitas vezes, nem sequer podem acompanhar a educação de seus filhos; é saber que, por mais que se esforce, sempre terá que melhorar; é assumir a responsabilidade de que pode fracassar. Professores não são superheróis, são pessoas, são profissionais que dão tudo de si e precisam de amparo, de formação contínua de qualidade que privilegie as competências necessárias para o exercício de suas funções.

\section{REFERÊNCIAS}

ALMEIDA FILHO, José Carlos Paes de. Análise de abordagem como procedimento fundador e auto-conhecimento e mudança para o professor de língua estrangeira. In: ALMEIDA FILHO, José Carlos Paes de (Org.) O Professor de Língua Estrangeira em Formação. Campinas: Pontes Editores, 2005.

ASSIS-PETERSON, Ana Antônia. Universidade, escola e comunidade: teorizando e redesenhando práticas pedagógicas para novos letramentos no ensino crítico de línguas estrangeiras. Projeto de Pesquisa 348/CAP/ 2011. Mato Grosso, UFMT.

BARDIN, Laurence. Análise de conteúdo. Lisboa: Edições 70, 2000.

BARCELOS, Ana Maria Ferreira. Reflexões acerca da mudança de crenças sobre ensino e aprendizagem de línguas. Revista Brasileira de Linguística Aplicada, 2007, v. 7, p. 109-138.

BOGDAN, Robert; BIKLEN, Sarin. Investigação Qualitativa em Educação: uma introdução à teoria e aos métodos. Porto: Porto Editora, 1994.

BRANDÃO, Carlos Rodrigues. A Pergunta a Várias Mãos: a experiência da pesquisa no trabalho do educador. São Paulo: Cortez, 2003 (Série Saber com o Outro; v.1).

BRASIL, Ministério da Educação. Programa Institucional de Bolsas de Iniciação à Docência (PIBID). 2007. Disponível em: <portal.mec.gov.br/pibid>. Acesso em 01 de nov. 2018.

BRASIL, Ministério da Educação. Parecer Conselho Nacional de Educação, CNE/CP 009/2001. Disponível em: <http://portal.mec.gov.br/cne/arquivos/pdf/009.pdf>. Acesso em: 20 jan. 2019. 
CELANI, Maria Antonieta Alba. Ensino de línguas estrangeiras: ocupação ou profissão? In: LEFFA, Vilson José. (Orgs). O professor de línguas: construindo a profissão. Pelotas: UCpel, 2001.

COX, Maria Inês Pagliarini; ASSIS-PETERSON, Ana Antônia. Ser/Estar professor de inglês no cenário da escola pública: em busca de um contexto eficaz de ensino/aprendizagem. Polifonia, Cuiabá, v. 5, p. 1-26, 2002.

COX, Maria Inês Pagliarini; ASSIS-PETERSON, Ana Antônia. O drama do ensino de inglês na escola pública brasileira. In: Assis-Peterson, Ana Antônia. (org.). Línguas estrangeiras: para além do método. Cuiabá: EdUFMT, 2008.

DIAS, Maria Helena Moreira. O lugar do inglês na escola pública: (des)crenças de atores da escola e da comunidade. Cuiabá, 2006. Dissertação (Mestrado em Estudos de Linguagem) UFMT, 2006.

DIAS, Maria Helena Moreira.; ASSIS-PETERSON, Ana Antônia. O inglês na escola pública: vozes de pais e alunos. Polifonia, Cuiabá, v.12, n.2, p. 107-128, 2006.

ESTEVE, José Manuel. O mal-estar docente: a sala de aula e a saúde dos professores. São Paulo: EdUSC, 1999.

FREIRE, Paulo. Pedagogia da Autonomia: saberes necessários à prática educativa. 1. ed. São Paulo: Paz e Terra, 2005.

GIMENEZ, Telma. Desafios contemporâneos na formação de professores de línguas: contribuições da linguística aplicada. In: FREIRE, Maximina Maria; ABRAHÃO, Maria Helena Vieira.; BARCELOS, Ana Maria Ferreira (orgs.) Linguística aplicada e contemporaneidade. São Paulo: ALAB, Campinas: Pontes Editores, 2005.

GIMENEZ, Telma. Ensinar a aprender ou ensinar o que aprendeu? In: LIMA, Diógenes Cândido de. Ensino e Aprendizagem de Língua Inglesa: conversa com especialistas. São Paulo: Parábola Editorial, 2009.

GIMENEZ, Telma. Narrativa 14: permanências e rupturas no ensino de inglês em contexto brasileiro. In: LIMA, Diógenes Cândido de. (Orgs). Inglês em escolas públicas não funciona? Uma questão, múltiplos olhares. São Paulo: Parábola Editorial, 2011.

JORDÃO, Clarissa Menezes. Abordagem comunicativa, pedagogia crítica e letramento crítico: farinhas do mesmo saco? In: ROCHA, Hilsdorf Cláudia; MACIEL, Ruberval Franco. (Orgs). Língua estrangeira e formação cidadã: por entre discursos e práticas. São Paulo: Pontes Editores, 2015.

LEFFA, Vilson José. Metodologia do ensino de línguas. In: BOHN, Hilário. Inácio; VANDRESEN, Paulino. Tópicos em linguística aplicada: O ensino de línguas estrangeiras. Florianópolis: UFSC, 1988.

LEFFA, Vilson José. Aspectos políticos da formação do professor de línguas estrangeiras. In: LEFFA, Vilson José. (Orgs). O professor de línguas: construindo a profissão. Pelotas: UCpel, 2001. 
MAGALHÃES, Maria Célia Camargo. Projetos de formação contínua de educadores para uma prática crítica. 1997 . The Especialist, vol. 19 n², $169-184$.

MATO GROSSO. Lei Complementar n. 50, de 01 out. 1998. Dispõe sobre a Carreira dos Profissionais da Educação Básica de Mato Grosso. Diário Oficial, Cuiabá, 01 out. 1998. Disponível em: 〈http://www.al.mt.gov.br>. Acesso em: 10 nov. 2018.

MENDES, Enicéia Gonçalves. A radicalização do debate sobre inclusão escolar no Brasil. Revista Brasileira de Educação, Rio de Janeiro, v.11, n.33, p.387-405, 2006.

MOITA LOPES, Luiz Paulo da. A Função da aprendizagem de línguas estrangeiras na escola pública. In: Oficina de Linguística Aplicada: a natureza social educacional dos processos de ensino/aprendizagem de línguas. Campinas, SP: Mercado das Letras, 1996.

NÓVOA, Antônio. Formação de Professores e Profissão Docente. In: NÓVOA, Antônio. Os professores e a sua formação. Dom Quixote: Lisboa, 1997.

NÓVOA, Antônio. O Regresso dos Professores. Pinhais: Melo, 2011.

NÓVOA, Antônio. Vida de Professores. Porto Editora: 2013.

NÓVOA, Antônio. Professor se forma na escola. 2001. In: Revista Nova Escola. Disponível em: < https://novaescola.org.br/conteudo/179/entrevista-formacao-antonio-novoa >. Acesso em: 15 nov. 2018.

OLIVEIRA, Luciano Arruda. Ensino de língua estrangeira para jovens e adultos na escola pública. In: LIMA, Diógenes Cândido de. (Org.) Ensino e aprendizagem de língua inglesa: conversas com especialistas. São Paulo: Parábola Editorial, 2009.

PAIVA, Vera Lúcia Menezes de Oliveira e. O. Ilusão, aquisição ou participação. In: LIMA, Diógenes Cândido de. (Orgs). Inglês em escolas públicas não funciona? Uma questão, múltiplos olhares. São Paulo: Parábola Editorial, 2011.

PAIVA, Vera Lúcia Menezes de Oliveira e. Autonomia e complexidade: uma análise de narrativas de aprendizagem. In: FREIRE, Maximina Maria; ABRAHÃO, Maria Helena Vieira; BARCELOS, Ana Maria Ferreira. (Orgs.). Lingüística Aplicada e Contemporaneidade. Campinas e São Paulo: Pontes e ALAB, 2005.

PAPA, Solange Maria de Barros Ibarra. E. G. Prática Pedagógica Emancipatória: o professor reflexivo em processo de mudança - um exercício em Análise Crítica do Discurso. São Carlos: Pedro \& João Editores, 2008.

RAJAGOPALAN, Kanavillil. Por uma linguística crítica: linguagem, identidade e questão ética. São Paulo: Parábola Editorial, 2003.

RAJAGOPALAN, Kanavillil. O inglês como língua internacional na prática docente. In: LIMA, Diógenes Cândido de (Org.) Ensino e aprendizagem de língua inglesa: conversas com especialistas. São Paulo: Parábola Editorial, 2009.

Recebido em:29 de abril de 2019. 
Revista Prática Docente (RPD)

ISSN: 2526-2149

Aprovado em: 25 de junho de 2019. 